\title{
What makes a public open space liveable?
}

\author{
U. Dietrich \& N. Kengyel \\ HafenCity University Hamburg, Germany
}

\begin{abstract}
As part of a university course, a group of master students of architecture and urban planning evaluated different public urban spaces. The primary goal of the investigation was to identify which specific qualities create a successful urban space. In other words, which qualities make an urban space fulfil its practical purpose while also becoming enjoyable for communities? The secondary goal was to give students the opportunity to become aware of the importance of urban spaces and their impact on communities.

In order to determine the criteria that make an urban space liveable, they analysed positive and negative examples. They started off by taking the 12 Quality Criteria for Good Design of Public Spaces by Jan Gehl as a starting point. After reviewing it, students agreed that the criteria could be improved. They should include crucial aspects such as accessibility and they could also be formulated more precisely.

It is important to mention that especially in the case of negative examples, we need to reflect on the actions needed to improve the space; are the proposed changes to make the space better feasible or does the space elude such an improvement? This study will contain a final modified set of Jan Gehl's criteria, which will include examples of urban spaces that are perceived as positive and negative, their analysis and further proposals for improvement.

Keywords: design of public open spaces, liveability, human scale, protection, comfort, enjoyment.
\end{abstract}

\section{Introduction}

While architects concentrate on a building scale, urban planners operate at a larger scale. The design of public open spaces can be found somewhere between both disciplines.

For instance, when it comes to living units such as apartments, social contact is usually limited to our nuclear familiar circle such as family and friends. Public 
spaces on the other hand are areas that encourage us to interact with a much broader spectrum of society. They allow us to communicate with others; exchange opinions, enjoy ourselves, spend our spare time, etc. Sadly, this potential use is often overlooked and these areas are often dedicated to (automotive) traffic. As humans, it is part of our nature to enjoy being outdoors and to adapt to changing to various changing conditions [2]. Nowadays, urban planners tend to concentrate more on efficient transportation systems and less on urban spaces. Functional urban spaces have become a secondary priority, while real estate is the main focus of modern capitalist cities. The scale of buildings increases exponentially as well as the number of unattractive and dysfunctional urban spaces. As an end result of this dilemma we have communities spending most of their time indoors and living isolated lives in their apartments (fig. 1).

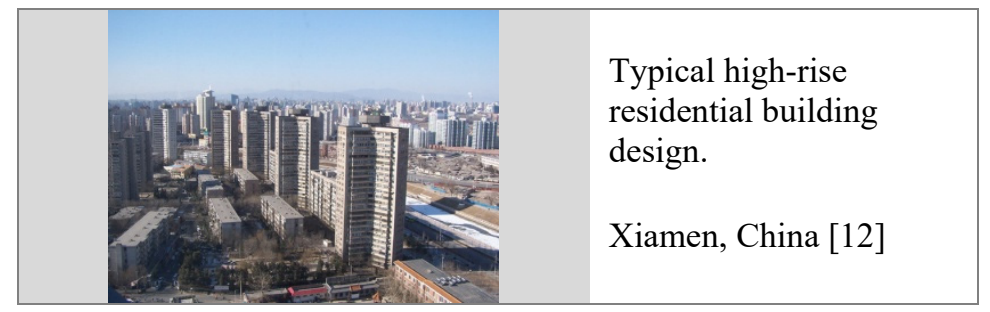

Figure 1: Layout for a complex of apartment towers in Xiamen, China, leading to dead public spaces, dedicated only to pass through.

Create a sequence of at least 6

photographs, which represent situations in outdoor urban spaces, on which you react spontaneously very positively or negatively.

Describe why you perceive the situation as positive/negative! Assess these situations according to Jan Gehl's the quality criteria for good design of public open spaces.

Are these criteria correct/complete?

Which one you would delete/change/add?

Would you use these criteria in your own work?

Which other experiences you made during the analysis should be mentioned?

Derive proposals for improvements of the chosen urban spaces, especially for the negatively felt of course.

Does the space allow these improvements or does it elude such changes?

Figure 2: Extract of the course exercise for master students of architecture and urban planning. 
In the light of this situation, the architect and urban planner Jan Gehl investigated the behaviour of people staying outdoors and looked for an answer to the question of What makes a public open space successful? Methods and results were published in many papers and books [3].

The final result is a matrix composed by 12 quality criteria for good design of public open spaces [1, see chapter 2].

In a course for master students of architecture and urban planning, groups of students were asked to analyse different public open spaces of their choice (fig. 2). They were to use Gehl's criteria as an assessment tool and contribute with their own ideas if possible.

Since the groups consisted of several international students, they contributed not only with experiences from local urban spaces but also from other urban spaces around the world.

\section{The 12 quality criteria from Jan Gehl for the good design of public open spaces}

A first draft of the criteria was developed in 1974 [4]. It was divided into three sections in a reasonable sequence. The first section deals with the obligatory precondition to stay outside at all: Protection (fig. 3).

\begin{tabular}{|c|c|c|c|}
\hline $\begin{array}{l}\mathbf{P} \\
\mathbf{R} \\
\mathbf{0} \\
\mathbf{T} \\
\mathbf{E} \\
\mathbf{C} \\
\mathbf{T} \\
\mathbf{I} \\
\mathbf{O} \\
\mathbf{N}\end{array}$ & $\begin{array}{l}\text { 1. Protection against } \\
\text { traffic \& accidents } \\
\text { - traffic accidents } \\
\text { - fear of traffic } \\
\text { - other accidents }\end{array}$ & $\begin{array}{l}\text { 2. Protection against } \\
\text { crime \& violence } \\
\text { (feeling of safety) } \\
\text { - lived in/ used } \\
\text { - streetlife } \\
\text { - streetwatchers } \\
\text { - overlapping functions } \\
\text { in space \& time }\end{array}$ & $\begin{array}{l}\text { 3. Protection against } \\
\text { unpleasant sense } \\
\text { experiences } \\
\text { - wind/draft } \\
\text { - rain/snow } \\
\text { - cold/heat } \\
\text { - pollution } \\
\text { - dust, glare, noise }\end{array}$ \\
\hline
\end{tabular}

Figure 3: First section of quality criteria - Protection.

The second section of the criteria deals with the preconditions to spend more time in a public space: Comfort (fig. 4). 


\begin{tabular}{|c|c|c|c|}
\hline \multirow[t]{2}{*}{$\begin{array}{l}\mathbf{0} \\
\mathbf{R} \\
\mathbf{T}\end{array}$} & $\begin{array}{l}\text { 4. Possibilites for } \\
\text { WALKING } \\
\text { - room for walking } \\
\text { - untiring layout of } \\
\text { streets } \\
\text { - interesting facades } \\
\text { - good surfaces }\end{array}$ & $\begin{array}{l}\text { 5. Possibilites for } \\
\text { STANDING / STAYING } \\
\text { - attractive edges } \\
\text { »Edgeeffect« } \\
\text { - defined spots for } \\
\text { staying } \\
\text { - supports for staying }\end{array}$ & $\begin{array}{l}\text { 6. Possibilites for } \\
\text { SITTING } \\
\text { - zones for sitting } \\
\text { - maximizing advan- } \\
\text { tages primary and } \\
\text { secondary sitting } \\
\text { possibilities } \\
\text { - benches for resting }\end{array}$ \\
\hline & $\begin{array}{l}\text { 7. Possibilities to SEE } \\
\text { - seeing-distances } \\
\text { - unhindered views } \\
\text { - interesting views } \\
\text { - lighting (when dark) }\end{array}$ & $\begin{array}{l}\text { 8. Possibilities for } \\
\text { HEARING / TALKING } \\
\text { - low noise level } \\
\text { - bench arrangements } \\
\text { »talkscapes« }\end{array}$ & $\begin{array}{l}\text { 9. Possibilites for } \\
\text { PLAY / UNFOLDING / } \\
\text { ACTIVITIES } \\
\text { - invitation to physical } \\
\text { activities, play, unfold- } \\
\text { ing \& entertainment - } \\
\text { day \& night and } \\
\text { summer \& winter }\end{array}$ \\
\hline
\end{tabular}

Figure 4: Second section of the quality criteria - Comfort.

The third section of criteria refers to amenities in public spaces (fig. 5).

\begin{tabular}{|c|c|}
\hline A & 10. Scale \\
M & \begin{tabular}{|l|} 
E \\
N
\end{tabular}$\quad \begin{array}{c}\text { - dimensioning of } \\
\text { buildings \& spaces } \\
\text { I } \\
\text { T } \\
\text { I } \\
\text { E } \\
\text { S }\end{array} \quad \begin{array}{c}\text { important human } \\
\text { dimensions related to } \\
\text { senses, movements, } \\
\text { size \& behaviour }\end{array}$ \\
\end{tabular}

\begin{tabular}{|l|}
\hline 11. Possibilities for \\
enjoying positive \\
aspects of climate \\
- sun/shade \\
- warmth/coolness \\
- breeze/ventilation
\end{tabular}

12. Aesthetic quality / positive sense experiences

- good design \& good detailing

- views/vistas

- trees, plants, water

Figure 5: Third section of quality criteria - Amenities.

\section{Students' findings, experiences and proposals for the modification of the 12 criteria}

Following the students' findings, experiences and proposals, the 12 criteria are modified, formulated more precisely and updated.

Further aspects will be mentioned in Section 4. They give important supplementary information but they are also too particular to be incorporated into the criteria. 


\subsection{Protection}

For criterion 1, it was proposed to modify Fear of traffic into Safety from all sorts of traffic (cars, cycles, pedestrians) and to add a new item: Clear separation of areas for people to walk and stand (fig. 6).

\begin{tabular}{|l|l|}
\hline $\begin{array}{l}\text { 1. Protection against } \\
\text { traffic \& accidents } \\
\text { - traffic accidents } \\
\text { - fear of traffic } \\
\text { - other accidents }\end{array}$ & $\begin{array}{l}\text { Safety from traffic and accidents } \\
\text { - Safety from all sorts of traffic (cars, bicycles, } \\
\text { pedestrians). } \\
\bullet \text { Clear separation of areas to walk and stand. }\end{array}$ \\
\hline
\end{tabular}

Figure 6: Modification of criterion 1 - Protection against traffic and accidents.

For criterion 2, a more precise formulation was proposed.

When referring to criterion 3, Protection against unpleasant sensory experiences, the elements of Crowd and Dirt need to be added (fig. 8). Dirt was often considered equally unpleasant as odours. Protection against wind can be offered in outdoor spaces; however, there is no effective way to protect people from unpleasant temperatures, which is why we withdrew the elements of heat/cold from the list (fig. 9).

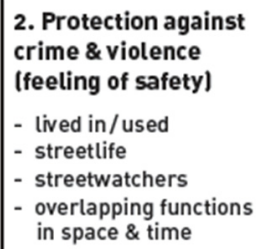

\section{Protection against crime and violence}

- Active public space

- Day and night active

- Good illumination by night

Figure 7: Modification of criterion 2-Protection against crime and violence.

A public space can be influenced negatively by its own success, attracting large crowds.

Calle Florida, Buenos Aires [5]

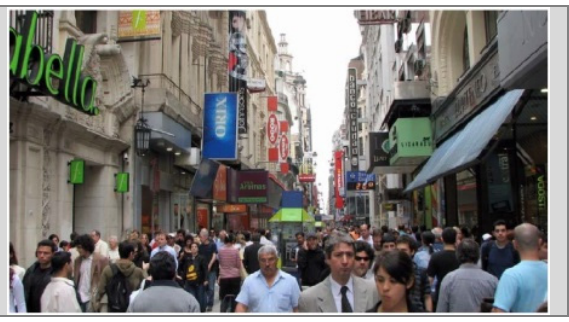

Figure 8: $\quad$ Supplement to criterion 3-Crowd [6]. 


\begin{tabular}{|l|l|}
\hline $\begin{array}{l}\text { 3. Protection against } \\
\text { unpleasant sense } \\
\text { experiences }\end{array}$ & $\begin{array}{l}\text { Protection against unpleasant sensory impressions } \\
\text { - wind/draft } \\
- \text { rain/snow } \\
- \text { cold/heat } \\
- \text { pollution } \\
- \text { dust, glare, noise }\end{array}$ \\
\hline
\end{tabular}

Figure 9: Modification of criterion 3 - Protection against unpleasant sensory impressions.

\subsection{Comfort}

For criterion 4 it was often mentioned that it is important that the public space is easy to reach and accessible. Bicycle racks on-site would not only be appreciated by cyclists but also by pedestrians (fig. 10).

\begin{tabular}{|l|l|}
\hline $\begin{array}{l}\text { 4. Possibilites for } \\
\text { WALKING }\end{array}$ & $\begin{array}{l}\text { Amenities for pedestrians } \\
\text { - room for walking } \\
\text { - untiring layout of } \\
\text { streets }\end{array}$ \\
$\begin{array}{l}\text { - interesting facades } \\
\text { - good surfaces }\end{array}$ & $\begin{array}{l}\text { - Easy to reach location and accessible to all } \\
\end{array}$ \\
\hline
\end{tabular}

Figure 10: Modification of criterion 4-Amenities for pedestrians.

Criterion 5 was renamed as Opportunities to enable longer stays. According to students' input, Good speech intelligibility (former Low noise level/criterion 8) is a precondition to stay for longer periods of time at a public space. Access to sanitaria and opportunities to buy something to drink or eat, day and night, are among other elements that encourage these longer stays (fig. 11).

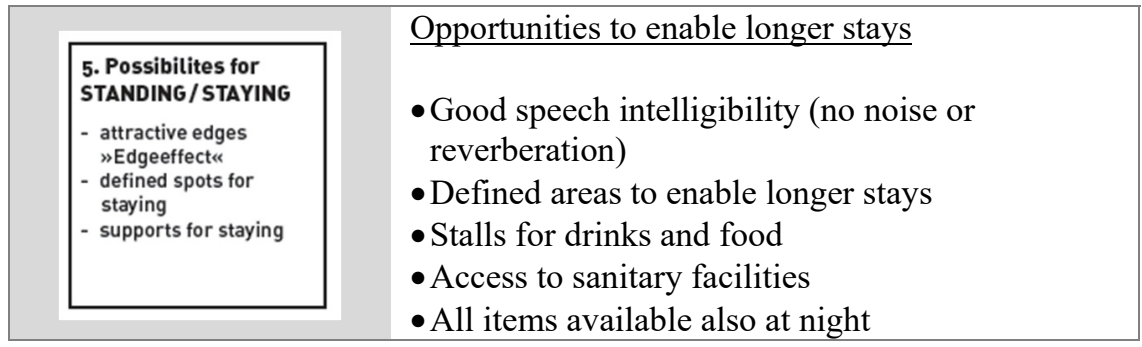

Figure 11: Modification of criterion 5-Opportunities to enable longer stays. 
Criterion 6 should also include standing and lying down. Places to sit are well arranged if there are primary as well as secondary seating options (fig. 12).

6. Possibilites for SITTING

- zones for sitting

- maximizing advan-

tages primary and

secondary sitting

possibilities

- benches for resting
Places to stand, sit and lie down

- Defined areas to sit

- Primary and secondary seating options

- Benches

Figure 12: Modification of criterion 6-Places to stand, sit and lie down.

A more precise title for criterion 7 is Areas for undisturbed sightseeing (fig. 13).

\begin{tabular}{|c|c|}
\hline 7. Possibilities to SEE & Areas for undisturbed sightseeing \\
\hline $\begin{array}{l}\text { - seeing-distances } \\
\text { - unhindered views } \\
\text { - interesting views } \\
\text { - lighting (when dark) }\end{array}$ & $\begin{array}{l}\text { - Vistas and views } \\
\text { - Contemplating/sightseeing without the feeling of } \\
\text { being watched } \\
\text { - One or more vertical protecting elements ("wall } \\
\text { in the back") }\end{array}$ \\
\hline
\end{tabular}

Figure 13: Modification of criterion 7 -Areas for undisturbed sightseeing.

Criterion 8 is renamed to Areas to communicate, which seems to be more accurate. The possibility to gather in small groups is also supplemented (fig. 14).

\begin{tabular}{|l|l|}
\hline $\begin{array}{l}\text { 8. Possibilities for } \\
\text { HEARING/TALKING } \\
\text { - low noise level } \\
\text { - bench arrangements } \\
\text { "talkscapes« }\end{array}$ & $\begin{array}{l}\text { Areas to communicate } \\
\text { • Variable seating arrangements in a way that two } \\
\text { but also more individuals can talk easily } \\
\text { - Areas to gather for small groups (elements to } \\
\text { lean on or to rest) }\end{array}$ \\
\hline
\end{tabular}

Figure 14: Modification of criterion 8 -Areas to communicate.

For criterion 9 Structural elements as incentives for activities is included (fig. 15). 


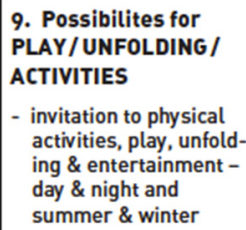

- invitation to physical

activities, play, unfold

ing \& entertainment -

day \& night and

summer \& winter

\section{Areas to play, relax and exercise}

- Enough area to move

- Structural elements as incentives for creative activities, movement, games and sports

- All available at all times of the day, regardless of the season

Figure 15: Modification of criterion 9-Places to play, relax and exercise.

\subsection{Enjoyment}

'To feel secure' was often suggested to be added to criterion 10, more precisely known as Human scale (fig. 16).

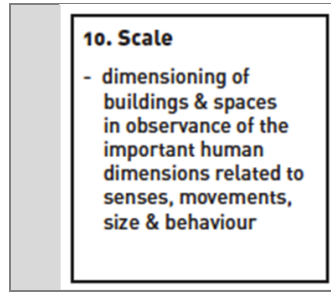

\section{$\underline{\text { Human scale }}$}

- Building scale and spaces ought to be proportional to human scale (senses, movements, size and behaviour)

- To feel secure

Figure 16: Modification of criterion 10 - Human scale.

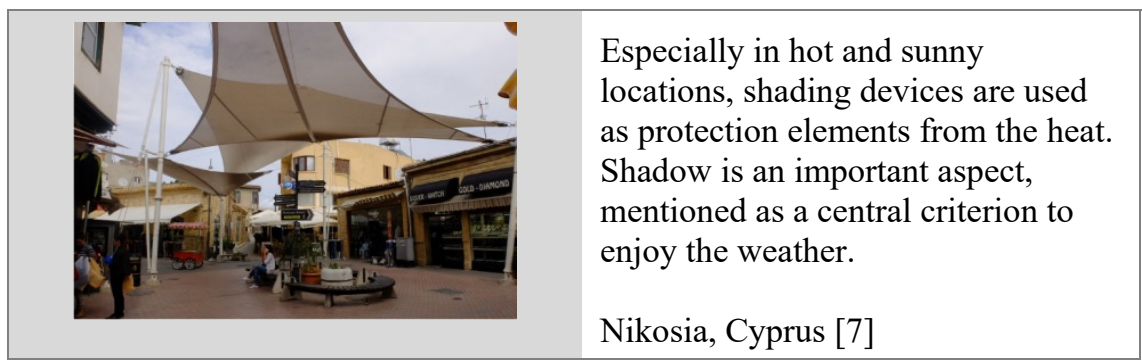

Figure 17: Supplement to criterion 11 - Shadow [7].

Criterion 11 remained nearly unchanged, except for the inclusion of Wind protection as the contrary to Cool Breeze (fig. 18). 


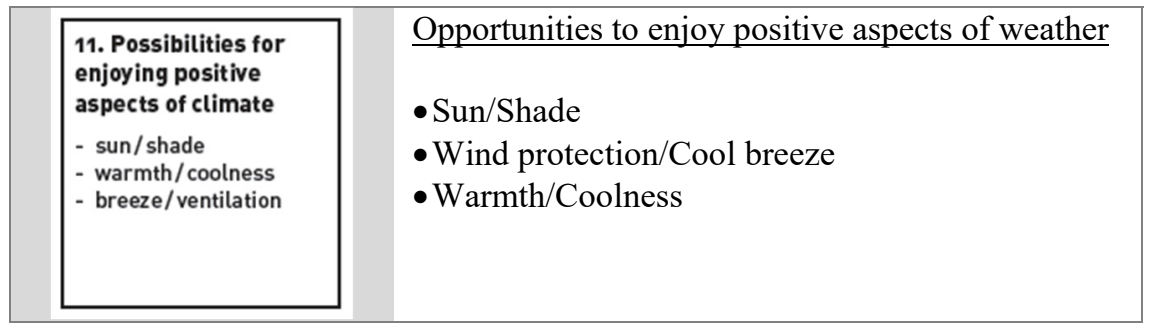

Figure 18: Modification of criterion 11 -Opportunities to enjoy positive aspects of weather.

Criterion 12 is the most discussed criterion because positive sensory impressions are very subjective. Nonetheless, all groups agreed on some criteria (figs 19 and 20).

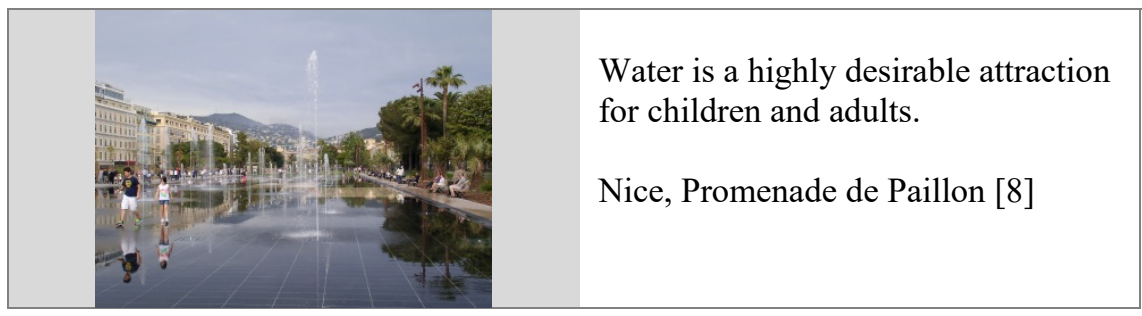

Figure 19: Supplement to criterion 12 - Water.

\begin{tabular}{|l|l|}
\hline $\begin{array}{l}\text { 12. Aestetic quality/ } \\
\text { positive sense } \\
\text { experiences }\end{array}$ & $\begin{array}{l}\text { Positive sensory impressions } \\
\text { - good design \& good } \\
\text { detailing }\end{array}$ \\
$\begin{array}{l}\text { - views/vistas } \\
\text { - trees, plants, water }\end{array}$ & $\begin{array}{l}\text { - Attractive views and vistas } \\
\end{array}$ \\
& - Trees, plants, water \\
& - Goodically and visually pleasant materials \\
& - Activities for people of all ages \\
& - Pleasant scent \\
\hline
\end{tabular}

Figure 20: Modification of criterion 12 - Positive sensory impressions.

\section{Further aspects to the 12 Criteria}

\subsection{Dominant positive aspects}

A positive perception can dominate a negative one. For example, sites like airports, railways and industrial facilities can become attractive when negative aspects such as noise and smell are not perceived because of a great distance. 
Designs with certain topographical properties can minimize these negative elements and at the same time optimize the positive ones (fig. 21).

The view onto the Hamburg port
becomes attractive from afar.
Park Fiction, Hamburg [9].
A smooth topographical design and
layout allows the possibility to watch
from the top or to be protected (from
wind, views of other people, sun etc.)
in lower levels [10].

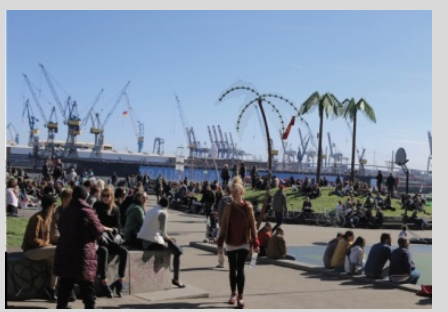

Figure 21: Example for dominant positive aspects.

\subsection{Other cultures}

The 12 criteria is a product derived from investigations in developed 'westernoriented' countries. Unconsciously, it is a mirror of this culture.

In order to apply it to other cultures the rules must be adapted respectively, especially in regards to communication, safe distances and enjoyment.

For example, drivers of vehicles with different velocities communicate with each other as well as they do with pedestrians. They create a safe atmosphere on the base of bilateral respect, even without a clear separation of traffic zones and areas to stay. The aspect of speed is much less important here (fig. 22).

\begin{tabular}{|l} 
A busy street in Vietnam without a \\
clear separation of traffic lines and \\
areas to stand. Pedestrians are safe \\
because they are in eye contact with \\
drivers and thus respected.
\end{tabular}

Figure 22: Example of a good functioning public space in a "non-western culture' (Vietnam) and it is widely not following the 12 quality criteria. 


\section{The modified 12 Quality Criteria for Good Design of Public Spaces at a glance}

\begin{tabular}{|c|c|c|}
\hline \multicolumn{3}{|l|}{ Protection } \\
\hline $\begin{array}{l}1 \text { Safety from traffic and } \\
\text { accidents }\end{array}$ & $\begin{array}{l}2 \text { Protection against } \\
\text { crime and violence }\end{array}$ & $\begin{array}{l}3 \text { Protection against } \\
\text { unpleasant sensory } \\
\text { impressions }\end{array}$ \\
\hline $\begin{array}{l}\text { - Safety from all sorts of } \\
\text { traffic (cars, bicycles, pe- } \\
\text { destrians) } \\
\text { - Clear separation of areas } \\
\text { to walk and stand }\end{array}$ & $\begin{array}{l}\text { - Active public space } \\
\text { - Day and night active } \\
\text { - Good illumination by night }\end{array}$ & $\begin{array}{l}\text { - Wind, precipitation, sun } \\
\text { - Dust, odour, dirt } \\
\text { - Crowd } \\
\text { - Noise } \\
\text { - Glare }\end{array}$ \\
\hline \multicolumn{3}{|l|}{ Comfort } \\
\hline $\begin{array}{l}4 \text { Amenities for pedes- } \\
\text { trians } \\
\text { - Easy to reach location and } \\
\text { accessible to all } \\
\text { - Bicycle racks } \\
\text { - Sufficient areas to walk } \\
\text { - Even, slip-free floor } \\
\text { covering } \\
\text { - Obstacle free }\end{array}$ & $\begin{array}{l}5 \text { Opportunities to enable } \\
\text { longer stays } \\
\text { - Good speech intelligibility } \\
\text { (no noise or reverberation) } \\
\text { - Defined areas to enable } \\
\text { longer stays } \\
\text { - Stalls for drinks and food } \\
\text { - Access to sanitary facilities } \\
\text { - All items available also at } \\
\text { night }\end{array}$ & $\begin{array}{l}6 \text { Places to stand, sit and } \\
\text { lay } \\
\text { - Defined areas to sit } \\
\text { - Primary and secondary } \\
\text { seating accommodations } \\
\text { - Benches }\end{array}$ \\
\hline $\begin{array}{l}7 \text { Areas for undisturbed } \\
\text { sightseeing } \\
\text { - Vistas and views } \\
\text { - Contemplating/Sightseeing } \\
\text { without the feeling of being } \\
\text { watched } \\
\text { - One or more vertical } \\
\text { protecting elements (.,wall } \\
\text { in the back“) }\end{array}$ & $\begin{array}{l}8 \text { Areas to communicate } \\
\text { - Variable seating arrange- } \\
\text { ments in a way that two but } \\
\text { also more individuals can } \\
\text { talk easily } \\
\text { - Areas to gather for small } \\
\text { groups (elements to lean } \\
\text { on or to rest) }\end{array}$ & $\begin{array}{l}9 \text { Areas to play, relax and } \\
\text { exercise } \\
\text { - Enough area to move } \\
\text { - Structural elements as } \\
\text { incentives for creative } \\
\text { activities, movement, } \\
\text { games and sports } \\
\text { - All available at all times of } \\
\text { the day, regardless of the } \\
\text { season }\end{array}$ \\
\hline \multicolumn{3}{|l|}{ Amenities } \\
\hline $\begin{array}{l}\text { - Building scale and spaces } \\
\text { ought to be proportional } \\
\text { to human scale (senses, } \\
\text { movements, size and be- } \\
\text { haviour) } \\
\text { - To feel secure }\end{array}$ & $\begin{array}{l}11 \text { Possibilities to enjoy } \\
\text { positive aspects of } \\
\text { weather } \\
\text { - Sun/shade } \\
\text { - Wind protection/cool } \\
\text { breeze } \\
\text { - Warmth/coolness }\end{array}$ & $\begin{array}{l}12 \text { Positive sensory } \\
\text { impressions } \\
\text { - Attractive views } \\
\text { - Trees, plants, water } \\
\text { - Haptically and optically } \\
\text { pleasant materials } \\
\text { - Good design } \\
\text { - Activities for people of all } \\
\text { ages } \\
\text { - Pleasant scent }\end{array}$ \\
\hline
\end{tabular}




\section{Final comments}

Jan Gehl's original work with the 12 criteria can be found in [4], it dates back to 1974. The corresponding graph shows that it was originally a matrix with key words for urban design. The 12 criteria were extracted from here as the rules for good design of public spaces, thus as rules for design. Other aspects like places to buy drinks and food etc. were mentioned in complete matrix but cut out by concentrating on design rules.

After some time, these 12 rules developed an independent existence and were cited again and again while the whole matrix was a bit forgotten.

The student's investigations showed that a concentration only on rules for design is not enough for the creation of successful public spaces. They are well a precondition but not the only one. Aspects like sanitaria's, speech intelligibility etc. are basic necessities to bring a space to success too.

In this work it is shown that also these further aspects could be summarized in the magic number of 12 criteria following Jan Gehl's example.

\section{Acknowledgement}

The authors thank Andrea Vergara for valuable hints and for proofreading the paper.

\section{References}

[1] http://onthecommons.org/magazine/12-steps-creating-communitycommons\#sthash.GPwsuWZT.dpuf, 2016.

[2] Baker, N., We are all outdoor animals, PLEA Conference 2000, Proceedings pp. 553-55, James \& James, London, 2000.

[3] Gehl, J., Life between buildings: using public space, New York: Van Nostrand Reinhold, 1987.

[4] Gehl, J., Svarre, B., How to study public life, Island press, 2013. p 106/107

[5] Picture: https://utta2010.wordpress.com/2011/12/13/florida-entre-el-brilloy-la-decadencia/, 2016

[6] Callau Poduje, P., Human Body and human Scale, MA course, Hafencity University, 2016.

[7] Biber, C., Human Body and human Scale, MA course, Hafencity University, 2016, Nikosia: (own picture).

[8] Picture: Own photograph Udo Dietrich.

[9] Haentjes, E., Human Body and human Scale, MA course, Hafencity University, 2016, Hamburg: (own picture).

[10] Gerlach, L., Human Body and human Scale, MA course, Hafencity University, 2016.

[11] Sarmiento, Y., Human Body and human Scale, MA course, Hafencity University, 2016, Hoi An: own picture.

[12] https://commons.wikimedia.org/wiki/File:Beijing_northeast.jpg, 2016. 